\title{
Teologia Fundamental e Juventude
}

Orientadora: Profa. Maria Clara Lucchetti Bingemer

Pesquisador: Igor Januário da Silva

Fonte: Voluntário

\section{Introdução}

Investigamos, a partir da contribuição do teólogo João Batista Libânio, o fenômeno da religião católica em meio à juventude. Dos jovens que entregam de maneira radical ao movimento pentecostal - por meio da Renovação Carismática Católica - a jovens com relações fluidas com a religião, inclusive com a de rejeição.

\section{Objetivos}

Estudar as condições possíveis de uma renovação da imagem e vivência da religião junto à juventude, a partir dos fundamentos da teologia fundamental de João Batista Libânio. 